\title{
Relationship of F-Be mineralization to granites and syenites at the Ermakovka deposit (Western Transbaikalia)
}

\author{
G.S. Ripp ${ }^{1} \quad$ I.A. Izbrodin ${ }^{1} \quad$ M.O. Rampilov ${ }^{1 *} \quad$ A.A. Tomilenko ${ }^{2} \quad$ E.A., Lastochkin ${ }^{1}$ \\ V.F. Posokhov ${ }^{1}$

\begin{abstract}
${ }^{1}$ Geological Institute Siberian Branch of the Russian Academy of Sciences Izbrodin E-mail: izbrodin@ginst.ru Rampilov E-mail: rampilov@ginst.ru
\end{abstract} \\ st. Sakh'yanovoi 6a, 670047 Ulan-Ude, Russia. Ripp E-mail: ripp@ginst.ru \\ Lastochkin E-mail: last@ginst.ru Posokhov E-mail: vitaf1@yandex.ru \\ ${ }^{2}$ Sobolev Institute of Geology and Mineralogy, Siberian Branch of the Russian Academy of Sciences \\ pr. Akademika Koptyuga 3, 630090 Novosibirsk, Russia. \\ Tomilenko E-mail: tomilen@igm.nsc.ru
}

${ }^{*}$ Corresponding author

\section{A B S T R A C T}

The paper presents the mineralogical and geochemical characteristics of two groups of hydrothermalites and their relation with igneous rocks of the Ermakovka deposit. The first group includes F-Be ore bodies, occurring outside the granite massif. The second group is presented in veinlets with sulfates, phosphates, kaolinite, muscovite and hematite. It contains Rare Earth Elements (REE) mineralization (monazite, florencite, xenotime) and occurs within the massif. There are two different massifs of igneous rocks (granite and syenite) at the area of the deposit which have ages (226-227Ma) close to the age of hydrothermalites (225Ma). Each of them could be a source of F-Becontaining veins. This paper reviews the ore potential of these rocks. It includes a mineralogical study isotopic analyses of $\mathrm{Sr}, \mathrm{Nd}$ and $\mathrm{O}$, and trace, including rare-earth element compositions and age determination (U-Pb) of F-Be ores. The data obtained by us evidence that the fluid source of F-Be ores were syenites rather than granites. This is proven by the absence of Be-mineralization in granites and schlieren pegmatites, and a sharp difference in composition of their fluid phases. A reductive fluid specification forming $\mathrm{F}-\mathrm{Be}$ ores (containing $\mathrm{CH}_{4}, \mathrm{H}_{2}$, $\mathrm{N}_{2}, \mathrm{CO}_{2}$ and $\mathrm{H}_{2} \mathrm{~S}$ ), contrasts sharply with fluid specification of granites. The granites are characterized by high oxygen fugacity, due to ferric iron, sulfates and phosphates. Besides isotopic composition of oxygen in quartz (7.4 and $5.1 \% \delta^{18} \mathrm{O}$ V-SMOW respectively), initial Sr ratios (0.7056-0.7065 and 0.707-0.709 respectively) and REE compositions are different.

\section{INTRODUCTION}

One of the problems of endogenous deposits is the sources of ore-forming fluids and the relation with the igneous rocks. The detail isotopic and geochemical studying allow to clarify the issue. The complexity of this problem was revealed after conducting modern studies (including isotopic studies) found that fluids and components of metamorphic (Beal and Lentz, 2001; Valley, 1986), juvenile (mantle) sources (Ripp et al., 2018) and meteoric (BroomFendely et al., 2016; Johnson and Ripley, 1998; Taylor and O'Neil, 1977) origin participated in the formation of 
endogenous deposits. Magmatic melts, in addition to the separation of the fluid phase in the fractional crystallization process, can also cause recycling of water from tanks of different origin. When this occurs, the mixing of fluids, the quantitative ratios of which vary greatly (Taylor and O'Neil, 1977), take place. This determines the complex mechanism of the deposit formation. One of the tasks in this problem involves the establishment of a magmatic source that could provides the ore-forming fluid. We concerned the problem of relation between igneous rocks and hydrothermal ores and of a possible source of F-Be mineralization at the Ermakovka F-Be deposit, which is the largest deposit in the Western Transbaikalia beryllium province.

Some researches supposed the relation of F-Be ores with granites of the Shtok massif (Lykhin and Yarmolyuk, 2015; Reyf, 2008), although there are other alkaline igneous rocks within the ore field. The main argument to support this relation is similarity ages of the granite $(226 \mathrm{Ma}, \mathrm{U}-\mathrm{Pb}$, zircon) and F-Be ores (225Ma, Rb-Sr, fluorite) (Lykhin et al., 2001, 2010b). The data of termometry which established a high content of fluid in melt inclusions in quartz from granites enriched with alkalies and fluorine were also included in the evidence. Ore mineralization was mostly due to volatile release from a deep-seated pluton for which crystallization history and fluid exsolution can be tracked by three batches of magma intruded at the level of the ore deposition to form the Yermakovka stock (Reyf, 2008). However there is no explanation of the absence of Be-mineralization in the granite massif. In fact there are no any Be-bearing minerals in schlieren pegmatites located within the massif. It is known that pegmatites (with their high fluid saturation) are often contain ore mineralization, representing an intermediate link between magmatites and hydrothermalites (Frezzotti, 2001; Lowenstern and Thompson, 1995; Roedder, 1992). Detailed isotopic studies (Ripp et al., 2016b) established the participation of meteoric waters in formation of the deposit.

\section{GEOLOGICAL BACKGROUND}

The Ermakovka deposit is located in Western Transbaikalia, $160 \mathrm{~km}$ east of Ulan-Ude. It is a part of the Western Transbaikalian Be-bearing province, and is localized in the remnant of metamorphosed terrigenouscarbonate rocks among Late Paleozoic granites. The important feature of the deposit is association with the intraplate, Early Mesozoic riftogenic basin, which is filled with volcanic-sedimentary rocks (Lykhin and Yarmolyuk, 2015). The remnant is composed of metamorphosed biotite-quartz-feldspar schists, sandstones, Precambrian crystalline limestones, and dolomites. In the Late Paleozoic Period under the heat influence of the Angara-Vitim granite batholith, it underwent metamorphic transformations at the level of the amphibolite facies, led to the formation of crystalline schists, and the marbleization of carbonate rocks. In the latter, phlogopite, forsterite and tremolite formed.

Igneous rocks are represented by small massifs of gabbro-diorites, alkali syenites, leucogranites, and dikes of various compositions (Fig. 1). Leucogranites (the Shtok massif) and alkali syenites formed in the period $225-227 \mathrm{Ma}$ (U-Pb, zircon; Rb-Sr, K-feldspar respectively), while host granites beyond the remnant are dated at $316 \pm 2 \mathrm{Ma}$ (U-Pb, zircon) (Lykhin et al., 2001, 2010b; Lykhin and Yarmolyuk, 2015). Gabbro-diorites compose a tabularlike body 120-150m thick, consist mainly of amphibole and plagioclase. They are skarnified, scapolitized, and chloritized. It is suggested that gabbro-diorites served as a screen for ore-forming fluids (Kupriyanova et al., 2001). The massif of alkali syenites is $0.5 \mathrm{~km}^{2}$, located on the northern flank of the deposit and is composed mainly of K-feldspar (60-90\%), plagioclase (5-10\%) and small amount of quartz. The main dark-colored mineral is aegirine, the amount of which reaches $10 \%$. There are fluorite, apatite, zircon and titanite as accessory in syenites. The syenites are partly carbonatized (up to $5 \%$ of calcite) and contain alkali 10-13wt. $\%\left(\mathrm{Na}_{2} \mathrm{O}+\mathrm{K}_{2} \mathrm{O}\right), \mathrm{SiO}_{2}$ (60-64wt.\%), $\mathrm{Al}_{2} \mathrm{O}_{3}$ (16-18wt.\%), $\mathrm{CaO}(0.5-2.7 \mathrm{wt} . \%)$ and $\mathrm{MgO}$ (less than 1wt.\%).

The area of the Shtok massif formed by leucogranites is less than $0.5 \mathrm{~km}^{2}$. The apical part of them is denudated and drilled up to $1 \mathrm{~km}$. There are no Be-containing minerals, and processes of pyrytization, fluoritization and carbonatization, which are widespread in the F-Be ores, are absent in the Shtok massif. The leucogranites contain 72-76wt.\% of $\mathrm{SiO}_{2}, 8-9$ wt.\% of $\mathrm{Na}_{2} \mathrm{O}+\mathrm{K}_{2} \mathrm{O}, 11-13$ wt. $\%$ of $\mathrm{Al}_{2} \mathrm{O}_{3}$; the agpaitic index is 0.96-1.19. An important feature of the leucogranites is their high oxygen fugacity which is caused by ferric iron $\left(\mathrm{FeO}=0.12, \mathrm{Fe}_{2} \mathrm{O}_{3}=2.36\right.$ wt. $\left.\%\right)$ and the presence of hematite. The other feature is the presence of sulfates and phosphates. The latest are also found in schlieren pegmatites and quartz veinlets which contain hematite, florencite, monazite, anglesite and xenotime.

Most dikes classified as alkali syenites, syenite-diorite and dioritic porphyrites are pre-ore. Skarns located in southern part of the deposit have been formed during pre-ore stage. They are composed of vesuvianite, garnet (andradite) wollastonite and amphibole.

Fluorite-beryllium ores form lenses, veins, veinlets, mineralized breccias grouped into series of subparallel bodies reaching a few hundred meters in lenght. Their thickness ranges from tens of centimeters to a few tens of meters. The largest bodies have massive structure, unrestrained thickness with pinches, swells, branches. They 
are accompanied by veinlet mineralization. The massive ores formed as a result of metasomatic replacement of carbonate rocks (Kupriyanova et al., 2011; Novikova et al., 1994). Most of the contacts of ores and carbonate rocks have sharp boundaries.

The orebodies composed by $20-70 \%$ fluorite. The typomorphic minerals are K-feldspar, dolomite, calcite, apatite, quartz, pyrite; the subordinate minerals are albite, rutile, amphibole, galena, sphalerite. According to the predominant Be-bearing mineral (Novikova et al., 1994) orebodies are grouped into two types. In one of them, the main Be-bearing minerals are phenakite and bertrandite, while in the other the main Be-bearing minerals are eudidymite, leucophanite.
Beryllium minerals form a dissemination of irregularly shaped grains, spherulites, and fine nests (Fig. 2). Most of the phenakite is confined to the interstices of fluorite grains. Phenakite forms rounded bundles up to $1-3 \mathrm{~cm}$ in size in massive ores, and spherical crystals - in the veins enriched with carbonates. Bertrandite formed later than phenakiteand is more characteristic of the upper-deposit horizons. It is confined to the interstices of fluorite grains, makes nests, and veinlet-like aggregates often with interstices made of tabular crystals. Dolomite and calcite comprise up to $3-10 \%$ of the ore parageneses volume. Dolomite formed at an early stage. K-feldspar in massive ores is represented by dissemination and coarse-grained anchimonomineral aggregates. It is confined to the vein wall, along with phenakite in carbonate-enriched veins.

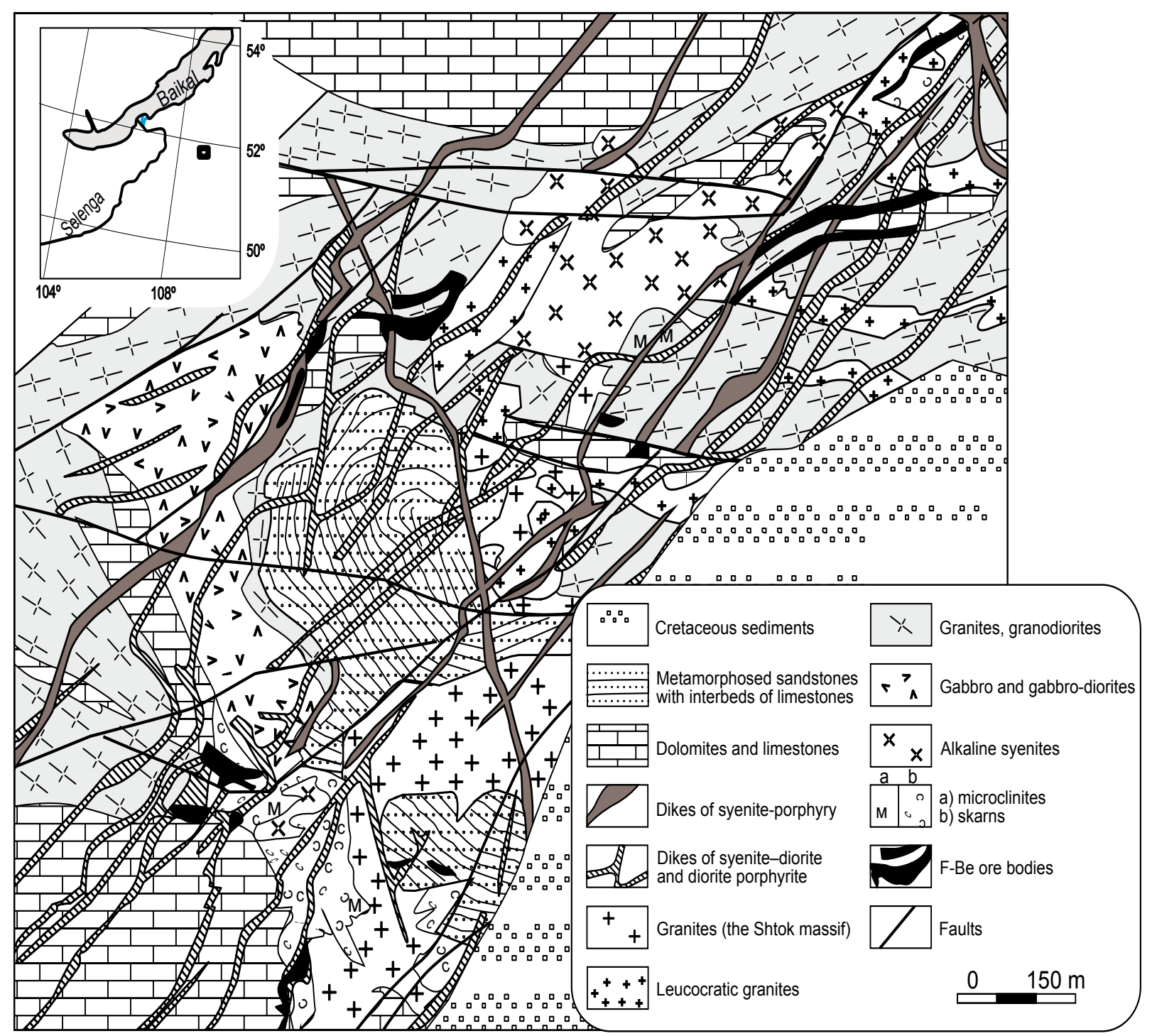

FIGURE 1. Geological context of the Ermakovka F-Be deposit. 

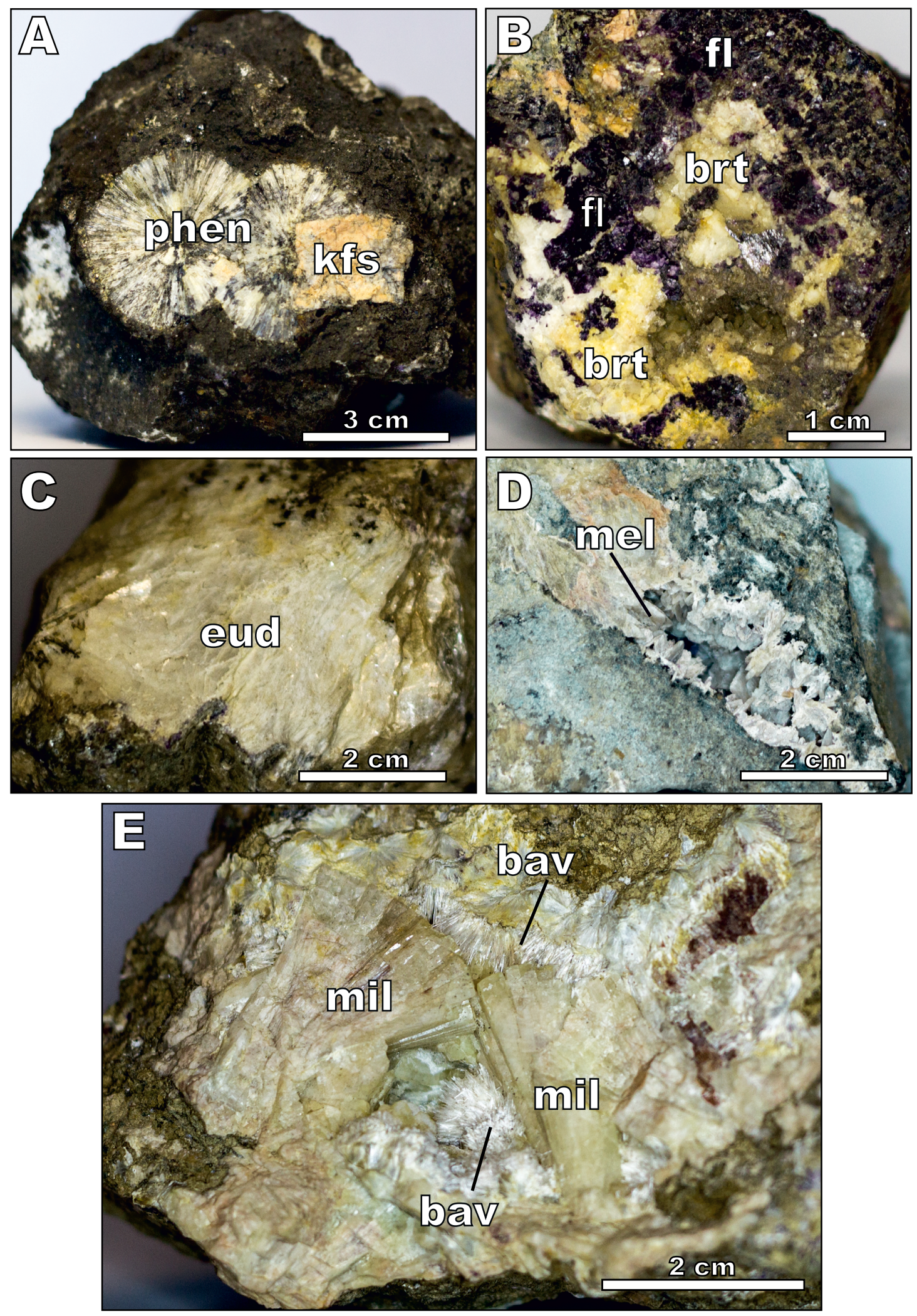

FIGURE 2. Images of hand samples of Be-minerals: A) spherulite of phenakite (phe) within calcite vein. Kfs: K-feldspar; B) irregular grains of bertrandite (brt) associated with fluorite (fl); C) Platy segregations of white eudidymite; D) meliphanite vein (mel); E) blocky, barrel-shaped crystals of greenish white milarite (mil) associated with white acicular bavenite (bav). 
Apatite is one of the earliest minerals; it forms prismatic crystals and their clustered aggregates. There is quartz up to $3-4 \%$, as well as dissemination and nest-like bodies of pyrite, sphalerite, and galena in the majority of ore bodies.

According to thermometry the deposit has been formed at $400-120^{\circ} \mathrm{C}$ (Damdinova and Reyf, 2004, 2008). There are three mineral assemblages: i) the earliest stage is pre-ore. Albitization and microclinization of hosted rocks have taken place during this stage at $300-400^{\circ} \mathrm{C}$; ii) the second stage is the main ore-forming. The majority of F-Be-ores have been formed at $200-310^{\circ} \mathrm{C}$ which is presented by phenakite, bertrandite, eudidimite, leucophanite, meliphanite and fluorite as the main mineral. Also microcline, apatite, dolomite, calcite, pyrite and alkali amphibole have been formed during this stage; iii) the majority of calcite has been formed during the latest stage $120-220^{\circ} \mathrm{C}$. Also some Be-minerals (phenakite, bertrandite) have been replaced by milarite and bavenite. The calcite veins formed during this stage contain pyrite, sphalerite, galena, molybdenite and microcline.

A chart of mineral formation sequence is presented in Figure 3. According to thermometry there is high amount of $\mathrm{CO}_{2}$ in fluid inclusions from ore minerals.

\section{ANALYTICAL METHODS}

The microtextural features, relations, and homogeneity of the minerals were studied by electron microscopy coupled with energy-dispersive spectrometry (SEM EDS). Most of the SEM EDS analyses were conducted on a Carl Zeiss LEO1430VP (LEO Electron Microscope) electron microscope equipped with an INCA Energy 350 (Oxford Instruments Nanoanalysis) analytical system. Minerals were analyzed at $20 \mathrm{kV}$ accelerating voltage, $0.5 \mathrm{nA}$ beam current, and $50 \mathrm{~s}$ counting time. The detection limits of the elements were 0.2 $0.3 \mathrm{wt} . \%$, and the random analytical errors were for major (>10wt.\%), for minor (1-10wt.\%), and for trace (0.3-1wt.\%) elements $0.9,3.0$, and 13 relative $\%$, respectively. Minerals were analyzed by scanning over $>10 \mu \mathrm{m}^{2}$ rectangular spots (if the analyzed phases were larger than this area).

The oxygen isotopic composition in the silicates was analyzed using laser fluorination. All the measurements were carried out on a Finnigan MAT 253 mass spectrometer (ThermoFinnigan, Bremen, Germany) using a double inlet system for oxygen in silicates. The measurements were calibrated using international standards NBS-28 (quartz), NBS-30 (biotite) (Coplen, 1988) for silicates. The error of the values obtained did not exceed $0.2-0.3 \%$.

The isotopic composition of $\mathrm{Nd}$ and $\mathrm{Sr}$ was measured using a Triton multichannel mass spectrometer in a static

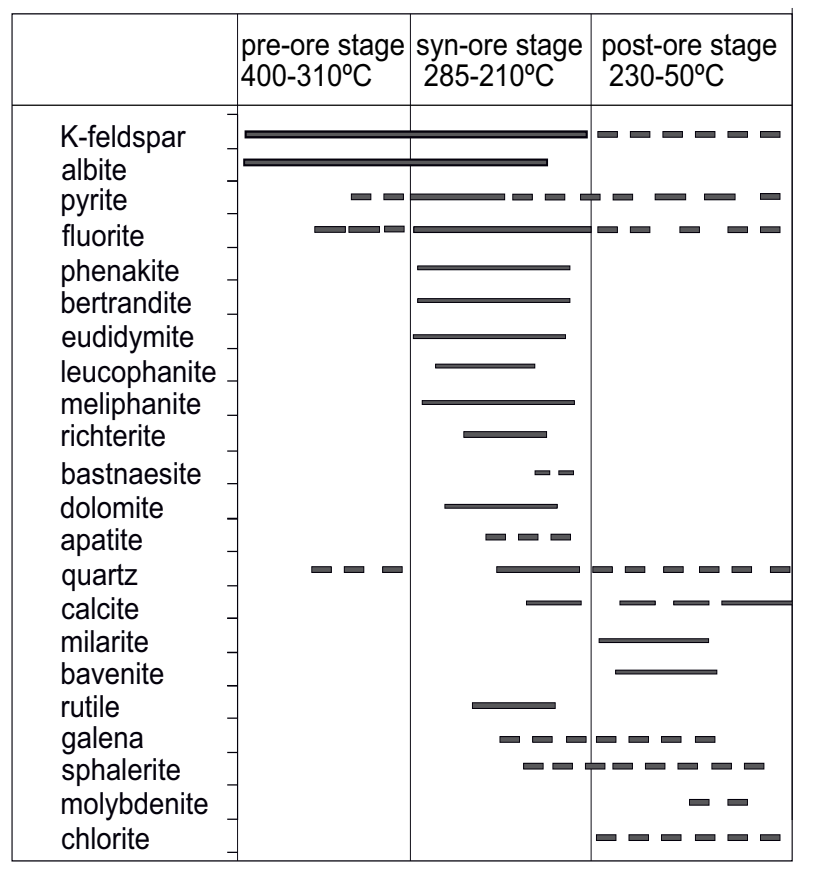

FIGURE 3. A chart of mineral formation sequence. Mineral composition and formation temperatures (Kosals et al., 1973) of pre-ore, syn-ore and post-ore stages are given.

regime. The reproducibility of the determinations of the $\mathrm{Rb}, \mathrm{Sr}, \mathrm{Sm}$, and $\mathrm{Nd}$ isotopic compositions was estimated to be $\pm 0.5 \%$ from the replicate analyses of the BCR (Basalt Columbia River) standard. The total blanks were $0.05 \mathrm{ng}$ for $\mathrm{Rb}, 0.2 \mathrm{ng}$ for $\mathrm{Sr}, 0.3 \mathrm{ng}$ for $\mathrm{Sm}$, and $0.8 \mathrm{ng}$ for $\mathrm{Nd}$. The results of the analysis of a standard BCR-1 sample (6 measurements) were as follows: $\mathrm{Sr}=336.7 \mu \mathrm{g} / \mathrm{g}, \mathrm{Rb}=$ $47.46 \mu \mathrm{g} / \mathrm{g}, \mathrm{Sm}=6.47 \mu \mathrm{g} / \mathrm{g}, \mathrm{Nd}=28.13 \mu \mathrm{g} / \mathrm{g},{ }^{87} \mathrm{Rb} /{ }^{86} \mathrm{Sr}=$ $0.4062,{ }^{87} \mathrm{Sr} /{ }^{86} \mathrm{Sr}=0.705036 \pm 22,{ }^{147} \mathrm{Sm} /{ }^{144} \mathrm{Nd}=0.1380$, ${ }^{143} \mathrm{Nd} /{ }^{144} \mathrm{Nd}=0.512642 \pm 14$. The reproducibility of the isotope analyses was evaluated using the measurements of the La Jolla and SRM-987 standards. Concurrently with the $\mathrm{Sr}$ measurements, the ${ }^{87} \mathrm{Sr} /{ }^{86} \mathrm{Sr}$ ratio in the SRM987 standard was found to be $0.710241 \pm 15(2 \sigma, 10$ measurements), whereas the value of ${ }^{143} \mathrm{Nd} /{ }^{144} \mathrm{Nd}$ in the La Jolla standard was $0.511847 \pm 8$ (2o, 12 measurements). The $\mathrm{Sr}$ isotope composition was normalized to ${ }^{88} \mathrm{Sr} /{ }^{86} \mathrm{Sr}=$ 8.37521, whereas the $\mathrm{Nd}$ composition was normalized to ${ }^{146} \mathrm{Nd} /{ }^{144} \mathrm{Nd}=0.7219$. The $\mathrm{Nd}$ isotope composition was corrected to ${ }^{143} \mathrm{Nd} /{ }^{144} \mathrm{Nd}=0.511860$ in the La Jolla standard.

The age of fluorite-phenakite-bertrandite ores was determined by apatite from two sites with the help of LAICP MS method. Apatite grains were placed on doublesided sticky tape and epoxy glue, then poured into a $2.5 \mathrm{~cm}$ diameter mould on top of the zircon grains and polished. The analyses were carried out using an Agilent 7900 ICP-MS quadrupole spectrometer connected to a $193 \mathrm{~mm}$ coherent ArF gas laser and Resonetics S155 ablation cell. 
The downhole fractionation, instrument drift and mass bias correction factors for $\mathrm{Pb} / \mathrm{U}$ ratios were calculated using two analyses on the primary zircon standards (Barfod et al., 2005; Chew et al., 2011) and two analyses on each of the secondary zircon standards (Amelin and Zaitsev, 2002; Chew et al., 2011; Schoene and Bowring, 2006), analyzed at the beginning of the session and every 12 unknown apatites, using the same spot size as used on the samples. The correction factor for the ${ }^{207} \mathrm{~Pb} /{ }^{206} \mathrm{~Pb}$ ratio was calculated using 2 analyses of the NIST610 standard analyzed throughout analytical session and corrected using the values (Baker et al., 2004). Each analysis began with a 30 second analysis of the blank gas measurement followed by a further 30 seconds of analysis time when the laser was switched on. Apatite was sampled on $29 \mu \mathrm{m}$ spots using the laser at $5 \mathrm{~Hz}$ and a density of approximately $2 \mathrm{~J} / \mathrm{cm}^{2}$. A flow of $\mathrm{He}$ gas at a rate of 0.35 litres/minute carried particles ablated by the laser out of the ablation cell to be mixed with Ar gas and carried to the plasma torch. Isotopes measured were ${ }^{31} \mathrm{P},{ }^{43} \mathrm{Ca},{ }^{56} \mathrm{Fe},{ }^{88} \mathrm{Sr},{ }^{149} \mathrm{Ce},{ }^{202} \mathrm{Hg},{ }^{204} \mathrm{~Pb},{ }^{206} \mathrm{~Pb},{ }^{207} \mathrm{~Pb},{ }^{208} \mathrm{~Pb}$, ${ }^{232} \mathrm{Th},{ }^{238} \mathrm{U}$ with each isotope being measured every $0.18 \mathrm{~s}$ with longer counting time on the $\mathrm{Pb}$ isotopes compared to the other isotopes. The data reduction used was based on the method outlined in (Meffre et al., 2008) with additional changes to correct low values of total lead in the primary standard, using the ${ }^{207} \mathrm{~Pb}$ correction according to (Chew et al., 2011).

A study of the fluid phase composition in fluorites from ores and granites of the Shtok massif was carried out by chromatography-mass spectrometry. The gas mixture released from fluid inclusions was analyzed on a Thermo Scientific (USA) DSQ II MS/Focus GC chromatography-mass spectrometer at the Institute of Geology and Mineralogy SB RAS. The preparations were placed in a special device included in the gas scheme of the chromatograph before the analytical column, heated at $140^{\circ} \mathrm{C}$ for 130 minutes in a He stream and destroyed by means of a punch. The gas mixture extracted from the sample during its impact destruction was entered online in a He flow without concentration, including cryofocusing. The separation of the sample into components was carried out in a gas chromatograph on a Restek Rt-QBOND capillary column. Ionization mass spectra by electron impact on the total ion current were obtained on a quadrupole mass-selective detector in the Full Scan mode. Mass spectral conditions: the electron energy is $70 \mathrm{eV}$, the emission current is $80 \mu \mathrm{A}$, the temperature in the ion source is $200^{\circ} \mathrm{C}$, the amplifier voltage is $1350 \mathrm{~V}$, the polarity of the detected ions is positive. The analysis start was synchronized with the sample destruction moment. Before and after the "working" analysis, blank online analyzes were carried out, which allowed to control the release of gases sorbed by the sample surface, including atmospheric components, and at the end of this process - to record the systock form. If necessary, the analytical column was thermally conditioned until the required blank was achieved.

Chromatography-mass spectrometry data with peak identification and extraction of individual components from overlapping peaks were interpreted using the software package AMDIS (Automated Mass Spectral Deconvolution and Identification Systock) version 2.66, and in manual mode with background correction using the NIST 2011 mass spectral libraries and Wiley 9 using the program NIST MS Search version 2.0. The relative concentrations of volatile components in the separated mixture were established by the normalization method: the sum of the areas of all chromatographic peaks of the analyzed mixture was equal to $100 \%$, and the individual component percentage in the analyzed mixture was determined by its area in the analyzed mixture (Sokol et al., 2017; Tomilenko et al., 2015).

\section{RESULTS}

This study was carried to assess the sources of fluids which formed the F-Be-mineralization. It includes the age determination of ores, and the geochemical characterization of igneous rocks and hydrothermalites. Special attention was paid to the hydrothermal mineralization within the Shtok massif. In this study, the geochemical data presented by Lykhin and Yarmolyuk (2015) is also included.

\section{Granites and pegmatites of the Shtok massif}

The Shtok massif, considered as a source of oreforming fluids, attracts the most attention of researchers among igneous rocks (Lykhin et al., 2010a; Reyf, 2008). It is formed by leucocratic subalkaline granites, which contain schlieren pegmatites. Hematitization and quartz veinlets are founded in some areas of the massif, and they are accompanied by leaching of K-feldspar and its replacement by kaolinite and muscovite. The processes of carbonatization and pyritization, which are widespread within the ore field are not found in the granites.

Zircon, apatite, titanite, monazite, xenotime, allanite, rutile and fluorite are accessory minerals in granites. Granites are characterized by low (2-5ppm) Be-concentration. There are neither elevated levels of beryllium in the dome-shaped juts of this stock nor beryllium minerals in pegmatites.

The most important feature of granites is its high oxygen fugacity, which caused the occurrence of almost exclusively ferric iron (in granite, $\mathrm{FeO}=0.12, \mathrm{Fe}_{2} \mathrm{O}_{3}=2.36$, in pegmatite $\mathrm{FeO}=0.08, \mathrm{Fe}_{2} \mathrm{O}_{3}=2.06$ ). Alkali sulfates were found in melt inclusions of granites and pegmatites (Reyf and Ishkov, 1999). 
The REE-normalized patterns for granites and pegmatites have a deep Eu-minimum and are identical to patterns for quartz veins which cut granites and contain sulphates and phosphates (Fig. 4). The Eu/Eu* values in them vary within $0.12-0.29$. The $(\mathrm{La} / \mathrm{Yb})_{\mathrm{n}}$ ratios are 2.40 2.98, $\mathrm{Th} / \mathrm{U}$ ratios are from 1 to 3 and $\mathrm{Sr} / \mathrm{Rb}$ ratios are from 0.1 to 10 .

The initial strontium ratios of granites and pegmatites are in the range of 0.7056-0.7065 (Table I, see appendix). The oxygen isotope composition in quartz from these rocks is in the range of 6.9-7.9\% $\mathrm{\delta} 18 \mathrm{O}$ (V-SMOW) (Table II; Fig. $5)$.

Alkali feldspars from syenites have high concentration of $\mathrm{BeO}$ (Lykhin and Yarmolyk, 2015). The REE-normalized patterns for syenites differ from granites and are similar to F-Be ores (see Fig. 4). There is no Eu-minimum and the $(\mathrm{La} / \mathrm{Yb})_{\mathrm{n}}$ ratios are in the range from 7 to 16 .

\section{Hydrothermalites}

There are two types of hydrothermalites at the deposit area, which are contrastingly different in mineral composition. The first type includes F-Be associations and is located outside the Shtok massif. Hydrothermalites of this type are described in detail in (Kupriyanova et al., 2011; Lykhin and Yarmolyuk, 2015). The obtained age (U-Pb, LA-ICP MS, apatite) of F-Be ores is $225.1 \pm 6.2 \mathrm{Ma}$ and 219 $\pm 1.2 \mathrm{Ma}$ (Fig. 6; Table III). The ores are enriched in light lanthanoids; they are distinguished by a slight slope of the content normalized patterns, and the absence of a Euminimum (Table IV). Their $(\mathrm{La} / \mathrm{Yb})_{\mathrm{n}}$ ratio averages 10.5 . The ores are also characterized by high $\mathrm{Sr} / \mathrm{Rb}$ (over 50) and
Th/U (50-100) ratios. The REE-normalized patterns differ from granites of the Shtok massif (see Fig. 4).

The primary $\mathrm{Sr}$ ratios in whole-rock samples and non$\mathrm{Rb}$ minerals exceed 0.707 , reaching in some cases 0.708 (see Table I). The ore-forming minerals, including quartz, have low $\delta^{18} \mathrm{O}$ values (see Table II). The $\delta^{18} \mathrm{O}$ values in carbonate minerals (Fig. 7) are also low. This indicates the involvement of the meteor source in the formation of the ores (Ripp et al., 2016b) together with deuterium depletion of water from hydroxyl-bearing minerals (from -130 to $-177 \%$ oD), as well as calculations of the oxygen content of equilibrium water with ore paragenesis minerals $(-2 \ldots$ $\left.-14 \delta^{18} \mathrm{O} \mathrm{H}_{2} \mathrm{O}\right)$.

The second type of hydrothermalites occurs inside the Shtok massif. It is represented by quartz veinlets with sulfates and phosphates. Some of the veinlets have a finegrained structure and a small thickness (less than $1 \mathrm{~cm}$, cements crushing zones in granites). They contain a large amount of corroded K-feldspar xenoliths, dissemination of monazite, xenotime and florencite (Fig. 8). The other part is represented by veinlets, up to several centimeters in thickness, up to 10 meters in length and is composed of quartz with caverns and interstices. The presence of caverns is probably a result of leaching of sulfates or halides. These veinlets are found on the northern flank of the massif, and confined to hematitization zones. Hematite is found in $\mathrm{K}$-feldspar in the form of dispersed dissemination, veinlets and sometimes large isolations. Ferric iron $(\mathrm{FeO}=0.16$, $\mathrm{Fe}_{2} \mathrm{O}_{3}=6.5 \mathrm{wt} . \%$ ) prevails in quartz veinlets. The quartz veinlets contain fine-scale muscovite, kaolinite, sulfate and phosphate minerals (see Fig. 8). They also contain fluorite and xenoliths of hematitized K-feldspar. The latter are

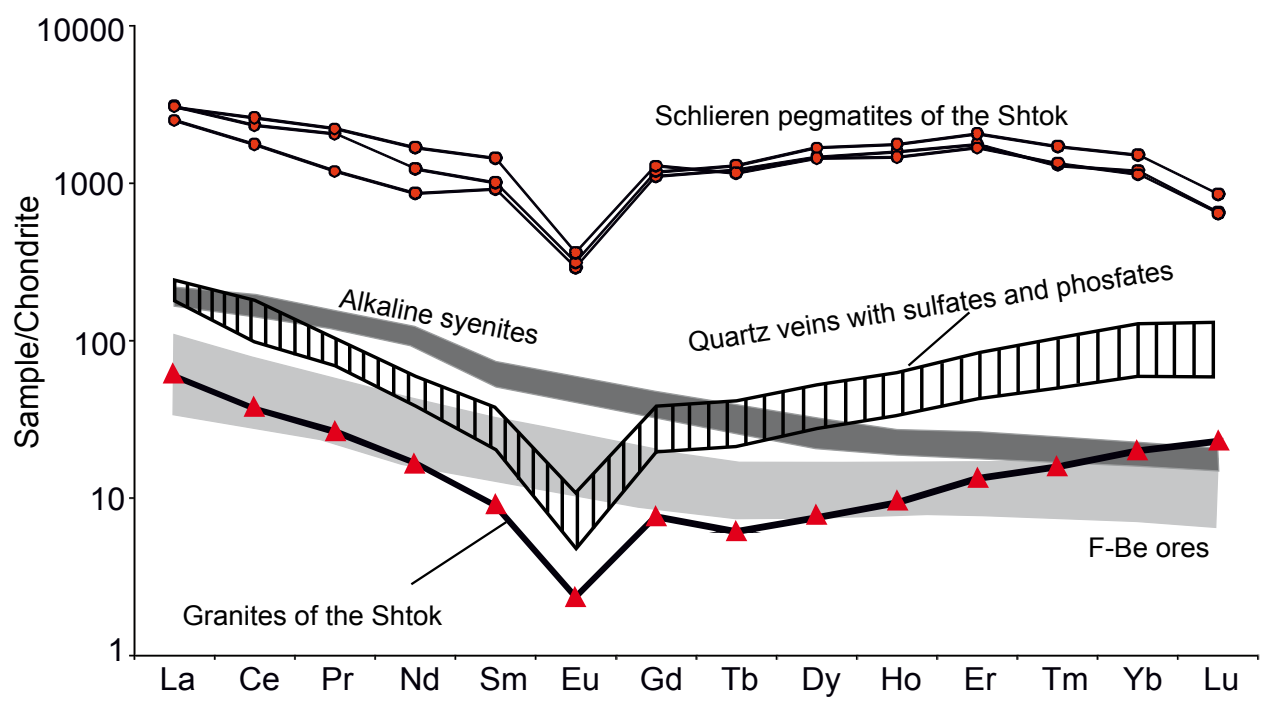

FIGURE 4. Chondrite-normalized REE concentration patterns (Sun and McDonough, 1989) of granites, alkaline syenites, schlieren pegmatites, quartz veins and $\mathrm{F}$-Be ores of the Shtok massif. 


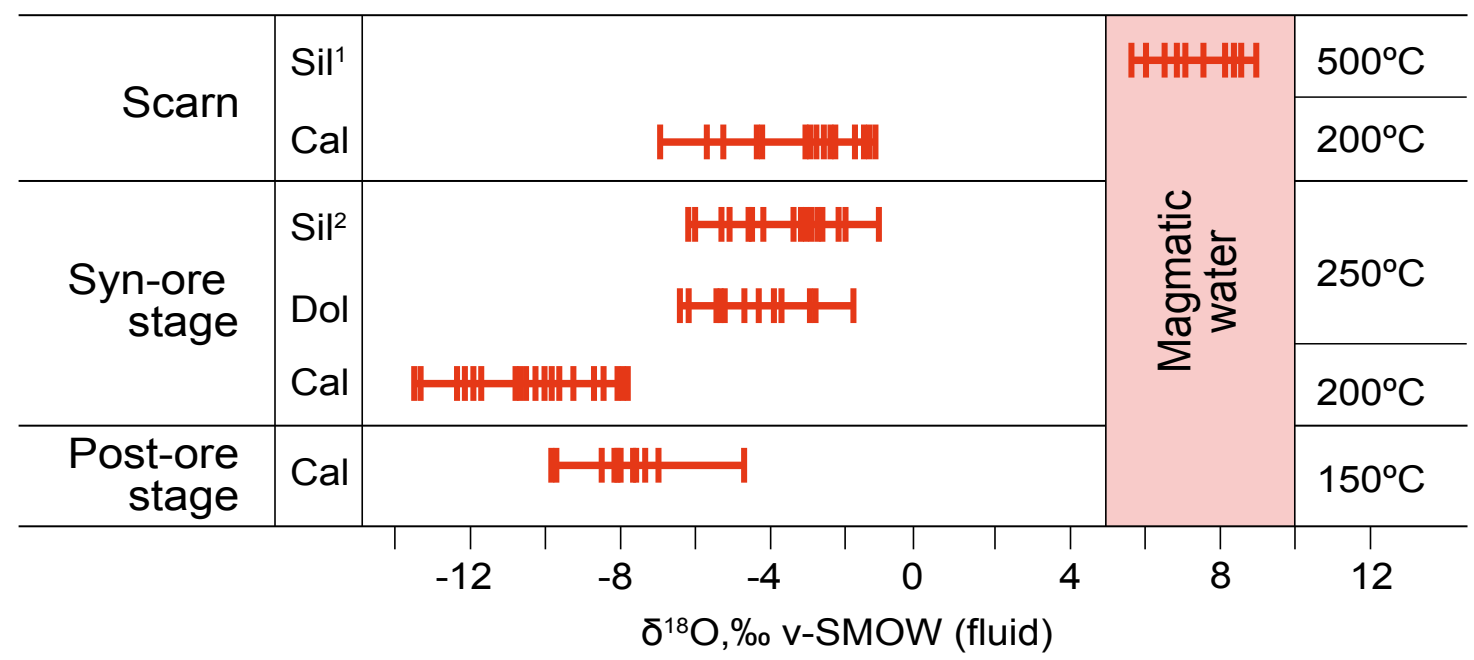

FIGURE 5. Oxygen isotope composition of fluids in equilibrium with minerals produced at different stages of formation of the Ermakovka deposit. Sil' ${ }^{1}$, Assemblage of silicate minerals in skarns (vesuvianite, andradite, wollastonite and amphibole); Sil2: assemblage of syn-ore stage minerals (K-feldspar, quartz, apatite, riebeckite and aegirine); Dol: dolomite; Cal: calcite.

argillized and muscovitized. There are jarosite, anhydrite, barite, glockerite among sulfates, and phosphates are represented by monazite, xenotime, florencite, which form dissemination and concentrations of grains of irregular and idiomorphic forms. A brecciation zone cemented by anhydrite was encountered in granites in one of the wells, at a depth of about 400 meters. This anhydrite contains veinlets and disseminations of mica and epidote. Mica from anhydrite contains 0.89apfu (atom per formula unit) of $\mathrm{Fe}$ and 1.95apfu of $\mathrm{Mg}$. The $\delta^{34} \mathrm{~S}$ value $(14.6 \%$ ) in anhydrite, is lower than in barites (25 and 33\%o) from F-Be ores.

Florencite is mainly confined to muscovite, monazite and xenotime to quartz (see Fig. 8). There is $0.9-1.5 \mathrm{wt} . \%$ of $\mathrm{SrO}$ in florencite, and there is phengite component (0.82.6apfu of Fe and 0.2-0.3apfu of $\mathrm{Mg}$ ) in muscovite.

The hydrothermally-altered granites (with hematitization) and quartz veinlets, have higher concentrations of REE, Y, $\mathrm{Th}, \mathrm{Ba}$, and chalcophile elements than unaltered granites (Table V; Fig. 9). The REE-normalized patterns for them are identical to the patterns for granites and schlieren pegmatites (see Fig. 4), they have a low Eu-minimum $\left(\mathrm{Eu} / \mathrm{Eu}^{*}=0.23\right.$ $0.28)$ and similar ratios $(\mathrm{La} / \mathrm{Yb}) \mathrm{n}$, which are 2.5. They also differ in low $\mathrm{Sr} / \mathrm{Rb}(0.1)$ and $\mathrm{Th} / \mathrm{U}(0.1-3)$ ratios. The oxygen isotope composition in quartz is characterized by its proximity to the composition of quartz from granites and pegmatites (see Table II).
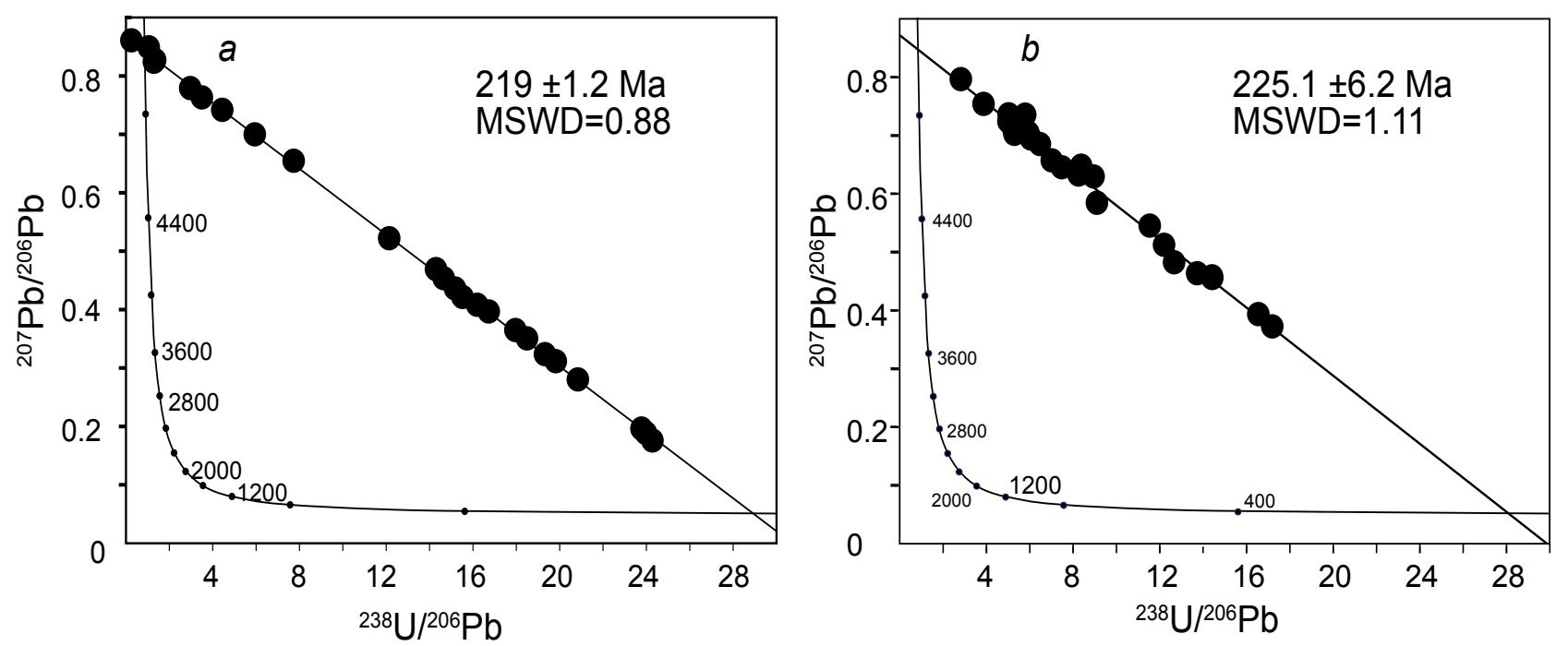

FIGURE 6. The Tera-Wasserburg diagrams with concordia for apatites from F-Be ores of the first zone of the Ermakovka deposit. 


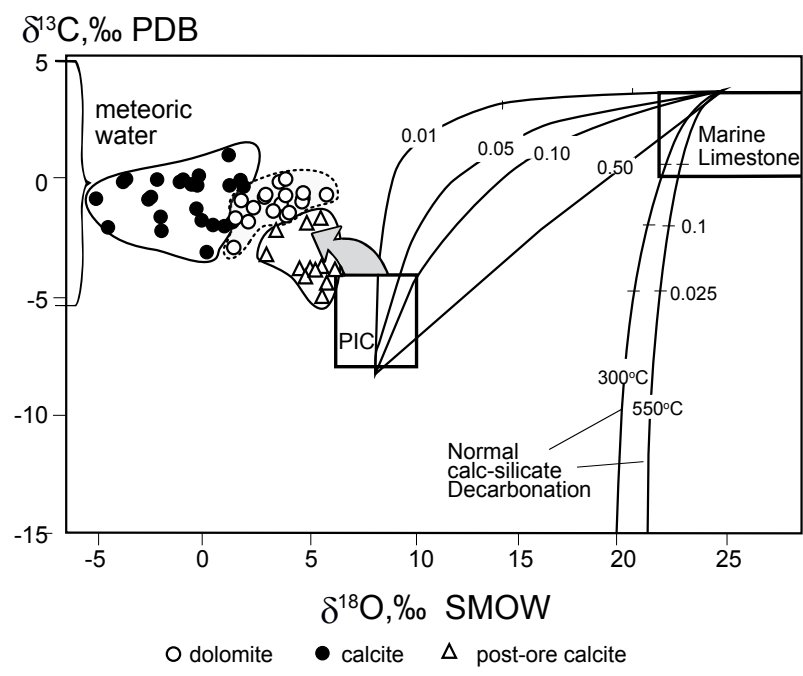

FIGURE 7. Arrangement of oxygen and carbon isotope compositions in carbonate minerals from the Ermakovka deposit relative to trends of mixing of mantle and sedimentary carbonate sources (Bowman, 1998). Numerals on the parabolas of theoretic mixing trends mark $\mathrm{CO}_{2}$ concentration in the solution (Taylor et al., 1967). At the upper corner curves for calc-silicate decarbonatization at $300-500^{\circ} \mathrm{C}$ (Baumgartner and Valley, 2001) are presented.

According to chromatography-mass spectrometry analysis of fluid inclusions in fluorites from granites and $\mathrm{F}-\mathrm{Be}$ ores (Table VI) the main volatiles are $\mathrm{H}_{2} \mathrm{O}$ and $\mathrm{CO}_{2}$. The fluorites from granites contain less $\mathrm{H}_{2} \mathrm{O}$ than one from the ores. The higher concentration of $\mathrm{CO}_{2}$ is in fluorites from granites. Apart from this there are hydrogen sulfide $\left(\mathrm{H}_{2} \mathrm{~S}\right)$, sulfur hexafluoride $\left(\mathrm{SF}_{6}\right)$, carbonyl sulfide (COS) and thiophenes. The main feature is the presence of molecular oxygen in fluid inclusions in fluorite from granites. A higher concentration of unsaturated hydrocarbons (alkenesalkynes) in fluid inclusions in fluorite from F-Be ores than in fluorite from granites indicates the oxidizing conditions for the formation of the latter.

\section{DISCUSSION}

One of important problems of the Ermakovka deposit is the source of the ore-forming fluids and a relationship between $\mathrm{F}-\mathrm{Be}$ ores and igneous rocks. Lykhin and Yarmolyuk (2015) supposed that the source of F-Be ores were granites of the Shtok massif because they have similar ages but the age of $\mathrm{F}-\mathrm{Be}$ ores $(225 \mathrm{Ma})$ is also close to the age of alkaline syenites $(227 \mathrm{Ma})$ which could also be a source of the ore-forming fluids. However these granites and schlieren pegmatites do not contain any Be-bearing minerals. The content of $\mathrm{Be}$ is in the range $2-5 \mathrm{ppm}$ and is similar to other granites of Transbaikalia.

Reyf and Ishkov (1999) suggested the existence of a specific fluid with high beryllium recovery efficiency.
The Shtok massif granites with sulfate and phosphate mineralization are less about this role. According to the known data on the solubility of beryllium compounds with different ligands (Wood, 1992), sulfate and chloride complexes are characterized by a minimum relative to other (fluoride and fluorine-carbonate) melt beryllium extraction. The latter is confirmed by the absence of beryllium in hydrothermalites that are widespread within the stock. The composition of the veinlets indicates that mainly chalcophile and rare-earth elements were removed from granites, and beryllium, lithium, cesium, titanium, and tin were not removed. Consequently, the Shtok massif granites should have formed not F-Be, but sulfate and phosphate mineralization.

The initial $\mathrm{Sr}^{87} / \mathrm{Sr}^{86}$ ratios and geochemical features of F-Be ores and granites of the Shtok (respectively, 0.7056 and more than 0.707 ) indicate different sources of them.

There are no carbonate minerals in granites but the F-Be ores contain up to $3-10 w t . \% \mathrm{CO}_{2}$. The suggestion about the occurrence of carbonates in ores as a result of the assimilation of limestones during their decarbonization is not supported by isotope studies (Ripp et al., 2016a). This is indicated by the sharp enrichment of carbonates of F-Be ores with low $\delta^{18} \mathrm{O}$ values up to $-2.5 \ldots+2.0 \%$ o $\delta^{18} \mathrm{O}$ with $15-22 \%$ in limestones (dolomites). The low $\delta^{18} \mathrm{O}$ values (mostly less than 3-5\%o) are also recorded in other (including beryllium) minerals of the ore phase (Ripp et al., 2016b).

The compositions of the fluid inclusions in fluorites from granites and F-Be ores are different. Hydrogen and methane are found in fluid inclusions in minerals of the latter (Kosals et al., 1973); it indicates the reducing nature of the ore-forming solutions. Granites (and schlieren pegmatites) have a sulfate and phosphate mineralization, which, together with the predominance of ferric iron and the presence of free oxygen in fluid inclusions, indicates a high fugacity of oxygen and their oxidative specificity.

The difference in the configuration of normalized rare-earth elements and, in particular, the presence of the europium anomaly in granites and the lack of it in F-Be ores (see Fig. 4), also testifies not in favor of their connection. At the same time, the inheritance of the configuration of the diagrams is fixed in hydrothermalites that are widespread within the granite stock.

Finally, the participation of meteor source water (Ripp et al., 2016b) in the fluids that formed the F-Be ores shows the need to explain its occurrence in the magmatic chamber and the mechanism for the release of such fluid. At least one model of its exudation, as a result of fractional crystallization, is no longer enough. 

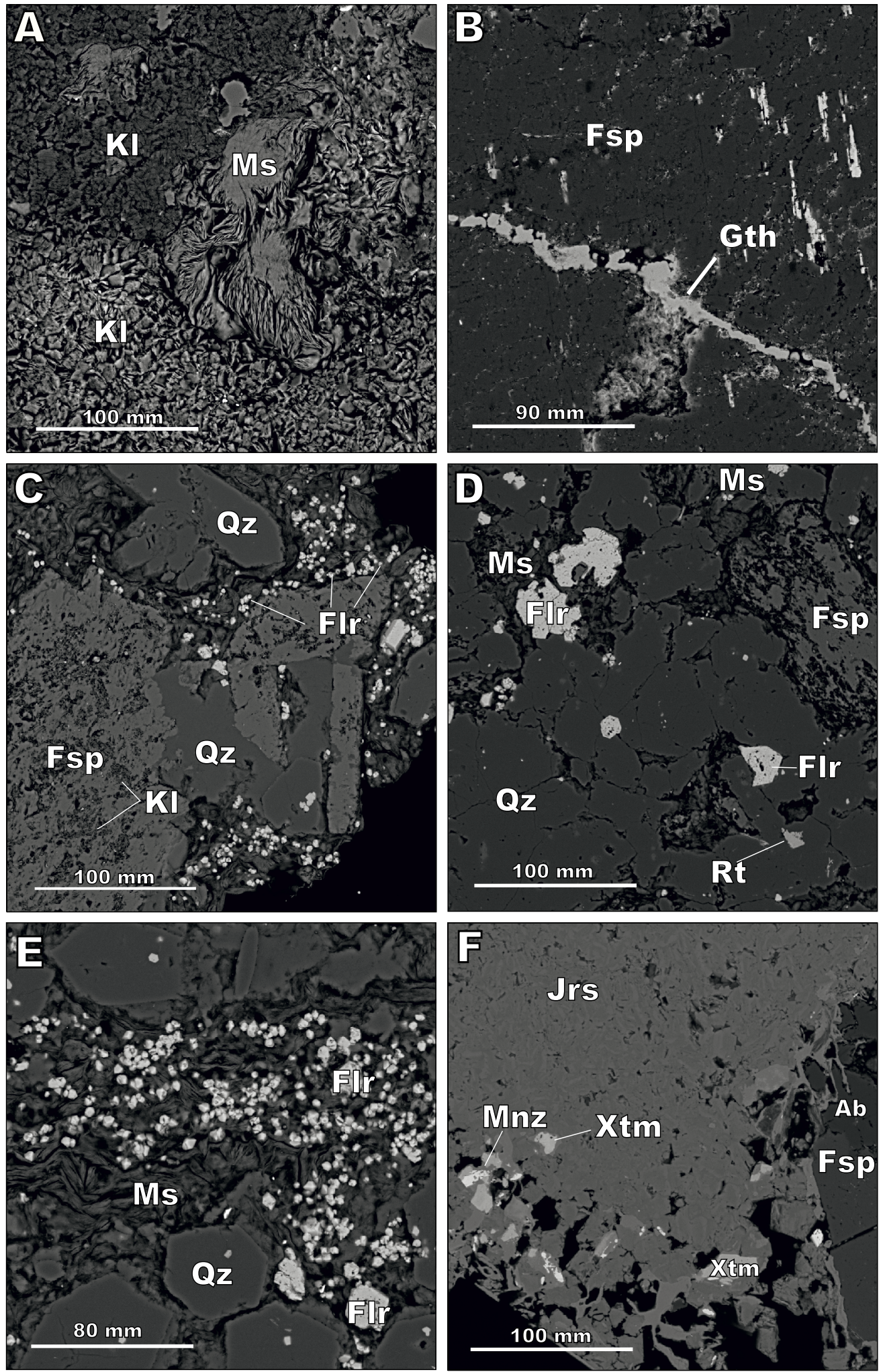

FIGURE 8. Composition and distribution of minerals in hydrothermalites common among the Shtok massif granites; A) typical kaolinite (KI) -muscovite (Ms) association in hydrothermalites, B) hematite (Gt) dissemination and veinlet in hydrothermally altered granites of the Shtok massif, C, D, E) florencite (FIr) dissemination in fine-grained muscovite (Ms) and quartz (Qz), Rt: rutile, Fsp: K-feldspar, F) isolation of fine-grained jarosite with xenotime (Xtm) and monazite (Mnz) dissemination. Ab: albite. 

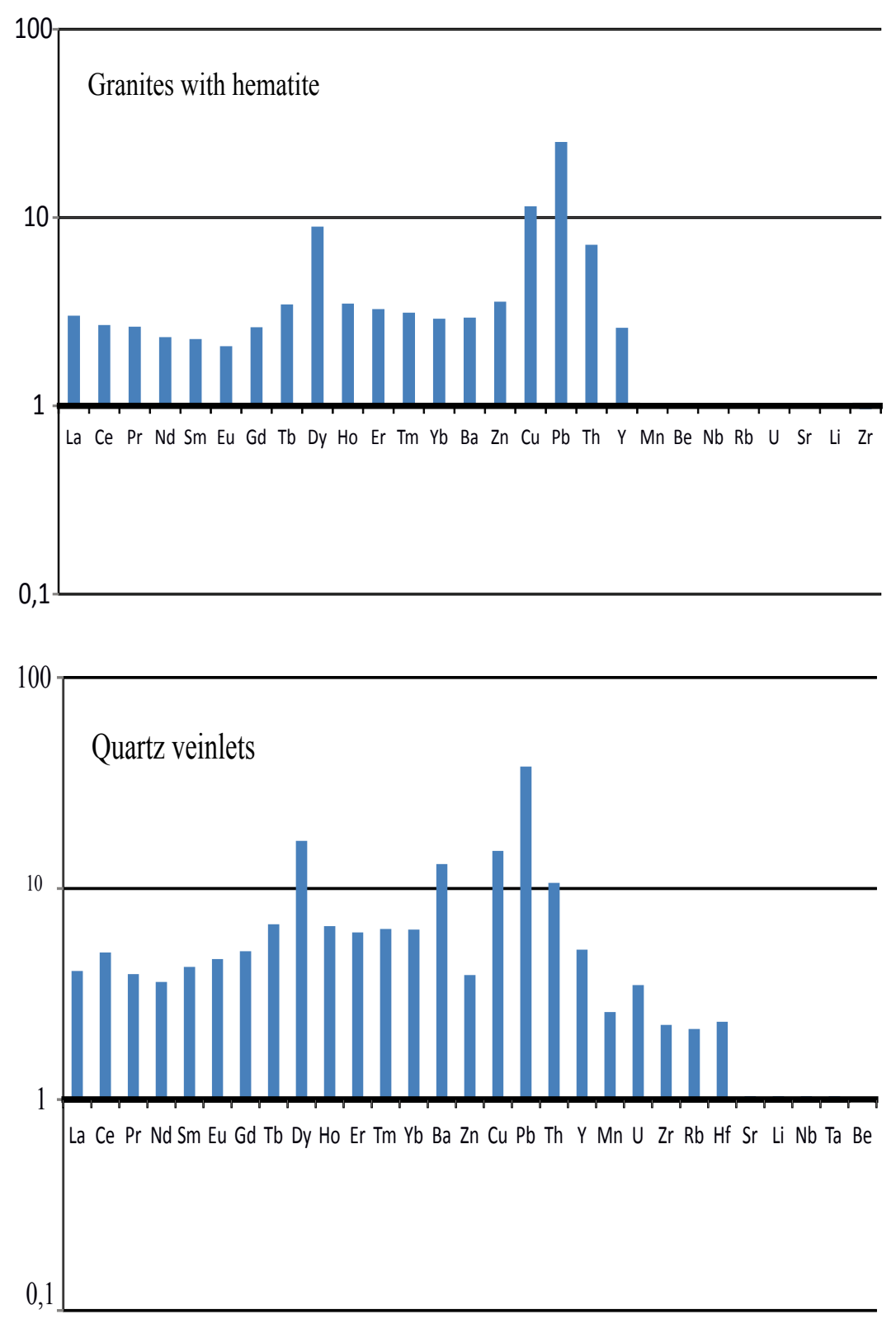

FIGURE 9. Trace element composition of quartz veinlets and granites with hematitization. The composition is normalized to unaltered granite of the Shtok massif.

A possible source of F-Be ores could be alkaline syenites. The $\mathrm{F}-\mathrm{Be}$ ores contain eudidymite, leucophanite, meliphanite, milarite and bavenite, such minerals usually common to alkaline rocks. The alkaline synenies of the Ermakovka contain high concentration of $\mathrm{Be}(22 \mathrm{ppm})$. The alkaline syenites normalized REE patterns are close to F-Be ones (see Fig. 4). Both alkaline syenites and F-Be ores have low $\delta^{18} \mathrm{O}$ values while the granites have higher $\delta^{18} \mathrm{O}$ values (7-7.93\%o). New U-Pb dating of apatite from F-Be ores has shown an age of $225 \mathrm{Ma}$, which is closed to the age of alkaline syenites (227Ma).

\section{CONCLUSION}

There are two types of hydrothermalites with contrasting compositions at the Ermakovka deposit. One of them, is represented by quartz veinlets with sulfate and phosphate minerals. They are specialized in REE and contain monazite, xenotime and florencite. These veinlets are located within the granites of the Shtok massif. The second type, is represented by F-Be ores. It occurs outside the granite massif.

Mineralogical and geochemical features of quartz veinlets with sulfate and phosphate minerals evidence a 
genetic relation with granites. The $\mathrm{F}-\mathrm{Be}$ ores have similar $\delta^{18} \mathrm{O}$ values, ages and REE-normalized patterns to alkaline syenites.

\section{ACKNOWLEDGMENTS}

Electron microscope analyses and oxygen isotopic compositions were carried out at the "Analytical Center of Mineralogical, Geochemical and Isotope Studies" at the Geological Institute, Siberian Branch of the Russian Academy of Sciences, Ulan-Ude, Russia. The isotopic composition of $\mathrm{Nd}$ and $\mathrm{Sr}$ was measured at the Institute of Precambrian Geology and Geochronology the Russian Academy of Sciences, St. Petersburg, Russia. The age of fluorite-phenacite-bertrandite ores was determined by LA-ICP MS method at the University of Tasmania, Hobart, Australia. This research was funded by the Russian Foundation for Basic Research (17-05-00129), grant of the President of the Russian Federation (MK-1014.2019.5) and project of fundamental research of the GIN SB RAS (reg. number AAAA-A16-116122110027-2).

\section{REFERENCES}

Amelin, Y., Zaitsev, A.N., 2002. Precise geochronology of phoscorites and carbonatites: The critical role of U-series disequilibrium in age interpretations. Geochimica et Cosmochimica Acta, 66(13), 2399-2419.

Baker, J., Peate, D., Waight, T., Meyzen, C., 2004. Pb isotopic analysis of standards and samples using a ${ }^{207} \mathrm{~Pb}-{ }^{204} \mathrm{~Pb}$ double spike and thallium to correct for mass bias with a doublefocusing MC-ICP-MS. Chemical Geology, 211(3-4), 275-303.

Barfod, G.H., Krogstad, E.J., Frei, R., Albarede, F., 2005. Lu-Hf and PbSL geochronology of apatites from Proterozoic terranes: A first look at Lu-Hf isotopic closure in metamorphic apatite. Geochimica et Cosmochimica Acta, 69(7), 1847-1859.

Baumgartner, L.P., Valley, J.W., 2001. Stable isotope transport and contact metamorphic fluid flow. Reviews in Mineralogy and Geochemistry, 43, 415-467.

Beal, K., Lentz, D.R., 2001. Aquamarine beryl from Zealand Station, Canada: a mineralogical and stable isotope study. Journal of geosciences, 55(1), 57-67.

Bowman, J.R., 1998. Stable-isotope systematics of skarn. Lentz, D.R. (ed.). Mineralized Intrusion-Related Skar Systems. Mineralogical association of Canada, short course, 26, 99-145.

Broom-Fendley, S., Heaton, T., Wall, F., Gunn, G., 2016. Tracing the fluid source of heavy REE mineralisation in carbonatites using a novel method of oxygen-isotope analysis in apatite: the example of Songwe Hill, Malawi. Chemical Geology, 440(15), 275-287.

Coplen, T.B., 1988. Normalization of oxygen and hydrogen data. Chemical Geology, 72(1-2), 293-297.

Chew, D.M., Sylvester, P.J., Tubrett, M.N., 2011. U-Pb and Th-Pb dating of apatite by LA-ICPMS. Chemical Geology, 280(1-2), 200-216.
Damdinova, L.B., Reyf, FG., 2004. Peculiarities of the formation of diverse veinlet beryllium mineralization at the Ermakovskoe deposit (Western Transbaikalia). Russian Geology Geophysics, 45(8), 979-991.

Damdinova, L.B., Reyf, FG., 2008. The origin of low-Be quartzfluorite field at the Ermakovskoe high-grade F-Be-ore deposit. Russian Geology Geophysics, 49(11), 816-826.

Frezzotti, M.L., 2001. Silicate-melt inclusions in magmatic rock: applications to petrology. Lithos, 55(1-4), 273-299.

Johnson, T.M., Ripley, E.M., 1998. Hydrogen and oxygen isotopic systematic of berillium mineralisation Spor Mauntain, Utah. Geological society of America, Abstract with programs, 30, 127.

Kosals, V.A., Dmitrieva, A.N., Arkhipchuk, R.Z., Galchenko, V.I., 1973. Sequence and features of formation of fluoritephenakite-bertrandite mineralization. Russian Geology Geophysics, 14(4), 42-53.

Kupriyanova, I.I., Shpanov, E.P., Galchenko, V.I., 2001. Ermakovka fluorite-beryllium deposit (Western Transbaikalia, Russia) (in Russian). Moscow, VIMS, 310pp.

Lowenstern, J.B., Thompson, J.F.H., 1995. Applications of silicatemelt inclusions to the study of magmatic volatiles, Magmas, Fluids, and Ore Deposits. Mineralogical Association of Canada, Short Course Series, 23, 71-99.

Lykhin, D.A., Kovalenko, V.I., Yarmolyuk, V.V., Kostitsyn, Y.A., Salnikova, E.B., Kotov, A.B., Kovach, V.P., Ripp, G.S., 2001. Ore-bearing magmatism at the Ermakovka beryllium deposit in the Western Transbaikal region: age, magma sources, and relationships to ore mineralization. Geology of Ore Deposits, 43(1), 46-63.

Lykhin, D.A., Kovalenko, V.I., Yarmolyuk, V.V., Kotov, A.B., Kovach, V.P., 2010a. The Yermakovsky deposit, Western Transbaikal region, Russia: isotopic and geochemical parameters and sources of beryllium-bearing granitoids and other rocks. Geology of Ore Deposits, 52(4), 289-301.

Lykhin, D.A., Kovalenko, V.I., Yarmolyuk, V.V., Salnikova, E.B., Kotov, A.B., Anisimova, I.V., Plotkina, Y.V., 2010b. The Yermakovsky Beryllium Deposit, Western Transbaikal Region, Russia: Geochronology of Igneous Rocks. Geology of Ore Deposits, 52(2), 126-152.

Lykhin, D.A., Yarmolyuk, V.V., 2015. West-Transbaikal beryllium province: deposits, ore-bearing magmatism, sources of matter (in Russian). Moscow, GEOS, 1-256.

Meffre, S., Large, R.R., Scott, R., Woodhead, J., Chang, Z., Gilbert, S.E., Danyushevsky, L.V., Maslennikov, V., Hergt, J.M., 2008. Age and pyrite $\mathrm{Pb}$-isotopic composition of the giant Sukhoi Log sediment-hosted gold deposit, Russia. Geochimica et Cosmochimica Acta, 72(9), 2377-2391.

Novikova, M.I., Shpanov, E.P., Kupriyanova, I.I., 1994. Petrography of the Ermakovskoe beryllium deposit, western Transbaikalia. Petrology, 2(1), 114-127.

Reyf, FG., Ishkov, Y.M., 1999. Be-bearing sulfate-fluoride brine: a product of residual pegmatite distillation in an alkali granite intrusion, Yermakovka F-Be deposit, Transbaikalia. Geochemistry International, 37(10), 985-999. 
Reyf, FG., 2008. Alkali granite and Be (phenakite-bertrandite) mineralization at the Orot and Yermakovka deposits. Geochemistry International, 46(3), 213-232.

Ripp, G.S., Izbrodin, I.A., Doroshkevich, A.G., Rampilov, M.O., Lastochkin, E.I., Posokhov, V.F., 2016a. Carbonates and sources of fluids in ores and metasomatites of the Ermakovka fluoritebertrandite-phenakite deposit (Western Transbaikalia). Russian Geology and Geophysics, 57(9), 1288-1297.

Ripp, G.S., Izbrodin, I.A., Lastochkin, E.I., Doroshkevich, A.G., Rampilov, M.O., Posokhov, V.F., 2016b. Isotopic Characteristics of the Ermakovskoe Fluorite-Bertrandite-Phenakite Deposit (Western Transbaikalia). Geochemistry International, 54(9), 748-764.

Ripp, G.S., Smirnova, O.K., Izbrodin, I.A., Lastochkin, E.I., Rampilov, M.O., Posokhov, V.F. 2018. An isotope study of the Dzhida Mo-W ore field (Western Transbaikalia, Russia). Minerals, 8, 546.

Roedder, E., 1992. Fluid inclusion for evidence immiscibility in magmatic differentiation. Geochimica et Cosmochimica Acta, 56(1), 5-20.

Schoene, B., Bowring, S.A., 2006. U-Pb systematics of the McClure Mountain syenite: Thermochronological constraints on the age of the ${ }^{40} \mathrm{Ar} /{ }^{39} \mathrm{Ar}$ standard MMhb. Contribution to mineralogy and petrology, 151, 615-630.

Sokol, A.G., Palyanov, Y.N., Tomilenko, A.A., Bul'bak, T.A., Palyanova, G.A., 2017. Carbon and nitrogen speciation in nitrogen-rich $\mathrm{C}-\mathrm{O}-\mathrm{H}-\mathrm{N}$ fluids at 5.5-7.8 GPa. Earth and Planetary Science Letters, 460, 234-243.

Sun, S., McDonough, W.F., 1989. Chemical and isotopic systematica of oceanic basalts: implications for mantle composition and processes. Magmatism in the ocean basins, 42, 313-345.

Taylor, H.P., Frechen, J., Degens, E.T., 1967. Oxygen and carbon isotope studies of carbonatites from the Laacher See district, West Germany and the Alno district, Sweden. Geochimica et cosmochimica acta, 31, 407-430.

Taylor, B.E., O’Neil, J.R., 1977. Stable isotope studies of metasomatic Ca-Fe-Al-Si-skarns and associated metamorphic and igneous rocks Osgood mountains, Nevada. Contribution to Mineralogy and Petrology, 63(1), 1-50.

Tomilenko, A.A., Chepurov, A.I., Sonin, V.M., Bul'bak, T.A., Zhimulev, E.I., Chepurov, A.A., Timina, T.Y., Pokhilenko, N.P., 2015. The synthesis of methane and heavier hydrocarbons in the system graphite-iron-serpentine at 2 and $4 \mathrm{GPa}$ and $1200^{\circ} \mathrm{C}$. High temperatures-high pressures, 44(6), 451-465.

Valley, J.W., 1986. Stable isotope geochemistry of metamorphic rocks. Reviews in Mineralogy and Geochemistry, 16, 445-489.

Wood, S.A., 1992. Theoretical prediction of speciation and solubility of berillium in hydrothermal solutions to $300^{\circ} \mathrm{C}$ at saturated vapor pressure: Application to bertrandite/phenakite deposits. Ore Geology Reviwes, 7(4), 249-278.

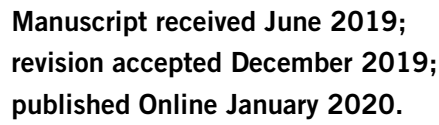




\section{APPENDIX I}

TABLE I. The Sri and $\varepsilon N d(T)$ values in mineral of the Ermakovskoe deposit

\begin{tabular}{llllrr}
\hline$№$ & Sample & Rocks & Mineral & $\varepsilon_{\mathrm{Nd}}(\mathrm{T})$ & $\mathrm{Sr}_{\mathrm{i}}$ \\
\hline 1 & 311 & Granites of the Shtok massif & Whole rock & 0.37 & 0.70772 \\
2 & 303 & $-/ /-$ & $-/ /-$ & 0.51 & 0.70653 \\
3 & 324 & $-/ /-$ & $-/ /-$ & -0.54 & 0.70617 \\
\hline 4 & $29 / 94$ & Schlieren pegmatite of the Shtok massif & Fluorite & & 0.70579 \\
5 & $29 / 94$ & $-/ /-$ & $-/ /-$ & 0.70574 \\
6 & $13 / 26$ & $-/ /-$ & $-/ /-$ & 0.70596 \\
\hline 7 & E-1 & F-Be ores & Fluorite & & 0.70772 \\
8 & E-1a & $-/ /-$ & Barite & & 0.70724 \\
9 & $1 / 95$ & $-/ /-$ & Apatite & & 0.70719 \\
10 & $1 / 95$ & $-/ /-$ & Fluorite & 0.70720 \\
11 & E-2 & $-/ /-$ & Whole rock & -2.45 & 0.707432 \\
\hline 12 & $6 / 94$ & Fluorite vein (selvedge) & Fluorite & & 0.70919 \\
13 & $6 \mathrm{a} / 94$ & Fluorite vein (centr) & Fluorite & & 0.70749 \\
\hline 14 & $190 / 92$ & Fluorite-feldspar vein & Fluorite & & 0.70694 \\
15 & E-3 & Apatite-fluorite-carbonate ores & Dolomite & -1.32 & 0.707346 \\
16 & E-4 & Fuorite-quartz vein (XII zone) & Whole rock & -1.86 & 0.707544 \\
17 & $12 / 94$ & $-/ /-$ & Fluorite & & 0.70831 \\
18 & $11 / 94$ & $-/ /-$ & Fluorite & & 0.70830 \\
19 & $12 / 94$ & $-/ /-$ & Fluorite & & 0.70901 \\
\hline 20 & $8 / 94$ & The latest fluorite vein & Fluorite & & 0.70770 \\
21 & $7 / 94$ & - // - & Fluorite & & 0.70739 \\
\hline
\end{tabular}

Note. Samples 1-3, after (Lykhin and Yarmolyuk, 2015) 
TABLE II. The $\delta^{18} \mathrm{O}$ in quartz from the Ermakovskoe deposit

\begin{tabular}{|c|c|c|c|}
\hline № & Sample & Rock & $\begin{array}{r}\delta^{18} \mathrm{O} \% \\
\mathrm{~V}-\mathrm{SMOW}\end{array}$ \\
\hline \multicolumn{4}{|c|}{ Granites of the Shtok massif } \\
\hline 1 & E-400 & Magmatic quartz & 7.1 \\
\hline 2 & E-300 & $-/ /-$ & 7.9 \\
\hline 3 & E-14-07 & $-/ /-$ & 7.4 \\
\hline 4 & $5 / 13$ & $-/ /-$ & 6.9 \\
\hline \multicolumn{4}{|c|}{ Schlieren pegmatite of the Shtok massif } \\
\hline 7 & $5 / 11$ & Quartz from the block zone & 7.2 \\
\hline 8 & $15 / 10$ & $-/ /-$ & 7.4 \\
\hline 9 & E-576 & $-/ /-$ & 7.6 \\
\hline \multicolumn{4}{|c|}{ Mineralized zones of the Shtok massif } \\
\hline 8 & $15 / 20$ & Quartz vein with REE mineralization & 6.4 \\
\hline 9 & $15 / 5$ & $-/ /-$ & 7.7 \\
\hline 10 & $15 / 6$ & $-/ /-$ & 7.6 \\
\hline 11 & $15 / 23$ & $-/ /-$ & 7.1 \\
\hline \multicolumn{4}{|c|}{ Quartz from ore bodies } \\
\hline 12 & $15 / 23 a$ & F-Be ores & 4.8 \\
\hline 13 & $15 / 18$ & $-/ /-$ & 0.8 \\
\hline 14 & $19 / 13$ & $-/ /-$ & 5.0 \\
\hline 15 & $31 / 13$ & $-/ /-$ & 4.4 \\
\hline 16 & $134 / 2$ & Fuorite-quartz vein (XII zone) & 5.8 \\
\hline 17 & E-4 & $-/ /-$ & 5.4 \\
\hline 18 & $4-1$ & K-feldspar-fluorite vein & 5.8 \\
\hline 19 & $5-4$ & Quartz-fluorite vein & 5.6 \\
\hline 20 & $15-16$ & Bavenite-quartz vein & 5.6 \\
\hline 21 & $15-1$ & $-/ /-$ & 5.7 \\
\hline
\end{tabular}

Note. Samples 1-2, after (Lykhin and Yarmolyuk, 2015) 
TABLE III. Results of U-Pb isotope analysis of apatite (LA-ICP-MS) from ores of the Ermakovskoe deposit

\begin{tabular}{|c|c|c|c|c|c|c|}
\hline № П.П & $\begin{array}{l}{ }^{206} \mathrm{~Pb} /{ }^{238} \mathrm{U} \\
\text { Age } \pm 1 \text { ster }\end{array}$ & ${ }^{206} \mathrm{~Pb} /{ }^{238} \mathrm{U} \pm \mathrm{RSE}$ & ${ }^{208} \mathrm{~Pb} /{ }^{232} \mathrm{Th} \pm \mathrm{RSE}$ & ${ }^{207} \mathrm{~Pb} /{ }^{206} \mathrm{~Pb} \pm \mathrm{RSE}$ & ${ }^{238} \mathrm{U} /{ }^{206} \mathrm{~Pb} \pm \mathrm{RSE}$ & ${ }^{207} \mathrm{~Pb} /{ }^{206} \mathrm{~Pb} \pm \mathrm{RSE}$ \\
\hline \multicolumn{7}{|c|}{ Sample E-19 } \\
\hline 1 & $223 \pm 29$ & $0.1727 \pm 0.037$ & $0.0261 \pm 0.026$ & $0.7359 \pm 0.028$ & $5.79 \pm 0.22$ & $0.7359 \pm 0.0205$ \\
\hline 2 & $216 \pm 13$ & $0.1117 \pm 0.022$ & $0.0158 \pm 0.015$ & $0.6296 \pm 0.021$ & $8.95 \pm 0.2$ & $0.6296 \pm 0.0131$ \\
\hline 3 & $216 \pm 14$ & $0.1193 \pm 0.023$ & $0.0176 \pm 0.017$ & $0.648 \pm 0.02$ & $8.38 \pm 0.19$ & $0.648 \pm 0.013$ \\
\hline 4 & $219 \pm 5$ & $0.0694 \pm 0.013$ & $0.0135 \pm 0.011$ & $0.4585 \pm 0.012$ & $14.42 \pm 0.18$ & $0.4585 \pm 0.0053$ \\
\hline 5 & $221 \pm 13$ & $0.0604 \pm 0.052$ & $0.0122 \pm 0.019$ & $0.3938 \pm 0.036$ & $16.56 \pm 0.87$ & $0.3938 \pm 0.0143$ \\
\hline 6 & $221 \pm 7$ & $0.0693 \pm 0.02$ & $0.0135 \pm 0.014$ & $0.4557 \pm 0.02$ & $14.43 \pm 0.29$ & $0.4557 \pm 0.0092$ \\
\hline 7 & $222 \pm 8$ & $0.0581 \pm 0.027$ & $0.012 \pm 0.013$ & $0.3727 \pm 0.029$ & $17.2 \pm 0.47$ & $0.3727 \pm 0.0106$ \\
\hline 8 & $227 \pm 10$ & $0.082 \pm 0.025$ & $0.016 \pm 0.015$ & $0.5125 \pm 0.023$ & $12.2 \pm 0.3$ & $0.5125 \pm 0.0118$ \\
\hline 9 & $228 \pm 9$ & $0.0728 \pm 0.025$ & $0.0125 \pm 0.013$ & $0.4637 \pm 0.023$ & $13.73 \pm 0.35$ & $0.4637 \pm 0.0104$ \\
\hline 10 & $233 \pm 14$ & $0.1211 \pm 0.022$ & $0.0196 \pm 0.016$ & $0.633 \pm 0.019$ & $8.26 \pm 0.18$ & $0.633 \pm 0.0121$ \\
\hline 11 & $236 \pm 7$ & $0.0789 \pm 0.019$ & $0.0145 \pm 0.013$ & $0.4826 \pm 0.018$ & $12.67 \pm 0.24$ & $0.4826 \pm 0.0085$ \\
\hline 12 & $218 \pm 23$ & $0.0867 \pm 0.047$ & $0.0129 \pm 0.021$ & $0.5456 \pm 0.056$ & $11.54 \pm 0.55$ & $0.5456 \pm 0.0306$ \\
\hline 13 & $249 \pm 14$ & $0.1336 \pm 0.021$ & $0.0157 \pm 0.013$ & $0.6455 \pm 0.018$ & $7.48 \pm 0.16$ & $0.6455 \pm 0.0117$ \\
\hline 14 & $249 \pm 13$ & $0.1098 \pm 0.023$ & $0.0178 \pm 0.016$ & $0.5845 \pm 0.021$ & $9.11 \pm 0.21$ & $0.5845 \pm 0.0125$ \\
\hline 15 & $253 \pm 12$ & $0.1685 \pm 0.01$ & $0.0173 \pm 0.011$ & $0.7049 \pm 0.007$ & $5.94 \pm 0.06$ & $0.7049 \pm 0.0052$ \\
\hline 16 & $255 \pm 10$ & $0.1425 \pm 0.011$ & $0.0127 \pm 0.011$ & $0.6574 \pm 0.009$ & $7.02 \pm 0.08$ & $0.6574 \pm 0.0057$ \\
\hline 17 & $269 \pm 14$ & $0.199 \pm 0.01$ & $0.0159 \pm 0.011$ & $0.7363 \pm 0.007$ & $5.03 \pm 0.05$ & $0.7363 \pm 0.0054$ \\
\hline 18 & $287 \pm 13$ & $0.1993 \pm 0.011$ & $0.0168 \pm 0.011$ & $0.7243 \pm 0.007$ & $5.02 \pm 0.05$ & $0.7243 \pm 0.0048$ \\
\hline 19 & $288 \pm 24$ & $0.1907 \pm 0.032$ & $0.0172 \pm 0.016$ & $0.7116 \pm 0.02$ & $5.24 \pm 0.17$ & $0.7116 \pm 0.0141$ \\
\hline 20 & $296 \pm 20$ & $0.1888 \pm 0.023$ & $0.0164 \pm 0.015$ & $0.7029 \pm 0.017$ & $5.3 \pm 0.12$ & $0.7029 \pm 0.0117$ \\
\hline 21 & $259 \pm 33$ & $0.1652 \pm 0.042$ & $0.0188 \pm 0.025$ & $0.6951 \pm 0.035$ & $6.05 \pm 0.26$ & $0.6951 \pm 0.0246$ \\
\hline 22 & $356 \pm 16$ & $0.2583 \pm 0.01$ & $0.0152 \pm 0.011$ & $0.7541 \pm 0.006$ & $3.87 \pm 0.04$ & $0.7541 \pm 0.0045$ \\
\hline 23 & $471 \pm 39$ & $0.3546 \pm 0.023$ & $0.0245 \pm 0.015$ & $0.7965 \pm 0.018$ & $2.82 \pm 0.07$ & $0.7965 \pm 0.0145$ \\
\hline \multicolumn{7}{|c|}{ Sample E-25 } \\
\hline 1 & $215 \pm 3$ & $0.0541 \pm 0.01$ & $0.1876 \pm 0.13$ & $0.3507 \pm 0.008$ & $18.49 \pm 0.19$ & $0.3507 \pm 0.0027$ \\
\hline 2 & $215 \pm 4$ & $0.0699 \pm 0.009$ & $0.0441 \pm 0.012$ & $0.4693 \pm 0.006$ & $14.3 \pm 0.13$ & $0.4693 \pm 0.0029$ \\
\hline 3 & $216 \pm 3$ & $0.0557 \pm 0.009$ & $1.5404 \pm 0.025$ & $0.3651 \pm 0.008$ & $17.96 \pm 0.16$ & $0.3651 \pm 0.003$ \\
\hline 4 & $216 \pm 2$ & $0.0505 \pm 0.008$ & $11.6583 \pm 0.034$ & $0.3117 \pm 0.007$ & $19.82 \pm 0.17$ & $0.3117 \pm 0.0021$ \\
\hline 5 & $217 \pm 4$ & $0.0598 \pm 0.011$ & $0.1448 \pm 0.03$ & $0.3969 \pm 0.011$ & $16.73 \pm 0.18$ & $0.3969 \pm 0.0044$ \\
\hline 6 & $217 \pm 2$ & $0.0518 \pm 0.008$ & $0.0589 \pm 0.012$ & $0.3237 \pm 0.006$ & $19.32 \pm 0.15$ & $0.3237 \pm 0.0018$ \\
\hline 7 & $217 \pm 2$ & $0.048 \pm 0.007$ & $0.2245 \pm 0.018$ & $0.2806 \pm 0.004$ & $20.84 \pm 0.15$ & $0.2806 \pm 0.0012$ \\
\hline 8 & $218 \pm 2$ & $0.0421 \pm 0.008$ & $0.2364 \pm 0.014$ & $0.1965 \pm 0.007$ & $23.77 \pm 0.19$ & $0.1965 \pm 0.0014$ \\
\hline 9 & $218 \pm 5$ & $0.0683 \pm 0.014$ & $1.9102 \pm 0.045$ & $0.4536 \pm 0.012$ & $14.65 \pm 0.21$ & $0.4536 \pm 0.0054$ \\
\hline 10 & $219 \pm 3$ & $0.0618 \pm 0.009$ & $0.3727 \pm 0.05$ & $0.4082 \pm 0.007$ & $16.19 \pm 0.14$ & $0.4082 \pm 0.0028$ \\
\hline 11 & $219 \pm 2$ & $0.0417 \pm 0.008$ & $11.1475 \pm 0.034$ & $0.1888 \pm 0.007$ & $23.98 \pm 0.19$ & $0.1888 \pm 0.0013$ \\
\hline 12 & $220 \pm 3$ & $0.0659 \pm 0.008$ & $0.0519 \pm 0.011$ & $0.4361 \pm 0.005$ & $15.18 \pm 0.12$ & $0.4361 \pm 0.0022$ \\
\hline 13 & $220 \pm 2$ & $0.0412 \pm 0.008$ & $0.3068 \pm 0.014$ & $0.1764 \pm 0.006$ & $24.28 \pm 0.18$ & $0.1764 \pm 0.0011$ \\
\hline 14 & $220 \pm 2$ & $0.0426 \pm 0.009$ & $0.3094 \pm 0.015$ & $0.1977 \pm 0.008$ & $23.5 \pm 0.2$ & $0.1977 \pm 0.0016$ \\
\hline 15 & $222 \pm 4$ & $0.0644 \pm 0.013$ & $0.9588 \pm 0.02$ & $0.4217 \pm 0.009$ & $15.52 \pm 0.21$ & $0.4217 \pm 0.004$ \\
\hline 16 & $222 \pm 5$ & $0.0824 \pm 0.011$ & $0.0514 \pm 0.019$ & $0.5222 \pm 0.009$ & $12.14 \pm 0.13$ & $0.5222 \pm 0.0045$ \\
\hline 17 & $230 \pm 9$ & $0.1293 \pm 0.014$ & $0.014 \pm 0.011$ & $0.6547 \pm 0.009$ & $7.73 \pm 0.11$ & $0.6547 \pm 0.0057$ \\
\hline 18 & $259 \pm 13$ & $0.1684 \pm 0.014$ & $0.0381 \pm 0.015$ & $0.7001 \pm 0.01$ & $5.94 \pm 0.09$ & $0.7001 \pm 0.0073$ \\
\hline
\end{tabular}


TABLE IV. The REE contents in granites, pegmatites, hydrotermalites and F-Be ores

\begin{tabular}{|c|c|c|c|c|c|c|c|c|c|c|c|c|c|c|c|c|c|}
\hline № & Sample & $\mathrm{La}$ & $\mathrm{Ce}$ & $\operatorname{Pr}$ & $\mathrm{Nd}$ & $\mathrm{Sm}$ & $\mathrm{Eu}$ & $\mathrm{Gd}$ & $\mathrm{Tb}$ & Dy & Ho & Er & $\mathrm{Tm}$ & $\mathrm{Yb}$ & $\mathrm{Lu}$ & $(\mathrm{La} / \mathrm{Yb}) \mathrm{n}$ & $\mathrm{Eu} / \mathrm{Eu}^{*}$ \\
\hline \multicolumn{18}{|c|}{ Granites of the Shtok massif } \\
\hline 1 & E-585 & 14.14 & 22.24 & 2.43 & 7.52 & 1.32 & 0.14 & 1.52 & 0.22 & 4.76 & 0.51 & 2.12 & 0.39 & 3.22 & 0.57 & 2.98 & 0.27 \\
\hline \multicolumn{18}{|c|}{ Schlieren pegmatite of the Shtok massif } \\
\hline 2 & Er-3/13(1) & 592 & 1075 & 110 & 394 & 136 & 16.3 & 220 & 43.5 & 360 & 86 & 282 & 32 & 193 & 16.1 & 2.08 & 0.29 \\
\hline 3 & Er-3/13(2) & 734 & 1430 & 190 & 560 & 148 & 17.5 & 235 & 46.7 & 410 & 95.9 & 330 & 42 & 243 & 20.9 & 2.05 & \\
\hline 4 & Er-13-П-2 & 723 & 1590 & 205 & 770 & 213 & 20.2 & 255 & 41.9 & 353 & 79.5 & 267 & 33 & 182 & 15.7 & 2.69 & 0.26 \\
\hline \multicolumn{18}{|c|}{ Hydrothermal mineralization in the massif } \\
\hline 5 & E-15-24 & 57.86 & 110.49 & 9.55 & 27.12 & 5.62 & 0.61 & 7.61 & 1.49 & 12.78 & 3.38 & 13.35 & 2.51 & 20.47 & 3.27 & 1.9 & 0.28 \\
\hline 6 & E-15-26 & 42.41 & 59.72 & 6.39 & 17.44 & 2.99 & 0.27 & 3.95 & 0.77 & 6.79 & 1.78 & 6.93 & 1.22 & 9.31 & 1.43 & 3.09 & 0.23 \\
\hline \multicolumn{18}{|c|}{ F-Be ores } \\
\hline 7 & $13 /$ ot & 107 & 121 & 10.4 & 23.2 & 4.0 & 0.63 & 2.6 & 0.43 & 3.4 & 0.81 & 2.8 & 0.42 & 3.8 & 0.38 & 19.12 & 0.56 \\
\hline 8 & Er.38/13 & 54.2 & 106.6 & 12 & 33 & 5.6 & 1.25 & 3.1 & 0.5 & 3.5 & 0.68 & 2.6 & 0.53 & 5.8 & 0.54 & 6.34 & 0.81 \\
\hline 9 & Er.133/12 & 16 & 22.7 & 2 & 7.4 & 1.8 & 0.5 & 1.7 & 0.5 & 2.2 & 0.5 & 1.3 & 0.3 & 2.3 & 0.24 & 4.72 & 0.85 \\
\hline 10 & Er.29/13 & 37.2 & 84.2 & 4.65 & 10.9 & 2.7 & 0.7 & 3.1 & 0.5 & 4.2 & 0.92 & 3.25 & 0.32 & 2 & 0.21 & 12.63 & 0.73 \\
\hline
\end{tabular}


TABLE V. The trace-element contents in rocks of the Stock massif

\begin{tabular}{|c|c|c|c|}
\hline Element & E-585 & E-15-24 & E-15-26 \\
\hline $\mathrm{Li}$ & 2.41 & 3.45 & 2.68 \\
\hline $\mathrm{Be}$ & 1.99 & 1.76 & 3.34 \\
\hline $\mathrm{Sc}$ & 1.25 & 1.35 & 1.09 \\
\hline $\mathrm{Ti}$ & 1127.6 & 962.5 & 494.08 \\
\hline V & 8.97 & 2.39 & 3.62 \\
\hline $\mathrm{Cr}$ & 1.45 & 3.85 & 1.98 \\
\hline $\mathrm{Mn}$ & 25.09 & 65.24 & 43.16 \\
\hline Co & 0.14 & 4.49 & 0.09 \\
\hline $\mathrm{Ni}$ & 0.14 & 6.28 & 0.76 \\
\hline $\mathrm{Cu}$ & 3.49 & 52.61 & 40.08 \\
\hline $\mathrm{Zn}$ & 44.94 & 174.39 & 160.88 \\
\hline $\mathrm{Ga}$ & 22.03 & 23.68 & 22.83 \\
\hline $\mathrm{Ge}$ & 1.41 & 1.38 & 1.15 \\
\hline $\mathrm{Rb}$ & 262.29 & 565.68 & 405.32 \\
\hline $\mathrm{Sr}$ & 30.87 & 53.68 & 36.89 \\
\hline Y & 19.19 & 98.44 & 49.92 \\
\hline $\mathrm{Zr}$ & 707.65 & 1593.9 & 679.17 \\
\hline $\mathrm{Nb}$ & 83.13 & 144.54 & 140.27 \\
\hline Mo & 0.52 & 21.47 & 30.24 \\
\hline $\mathrm{Ag}$ & 3.06 & 9.63 & 7.55 \\
\hline $\mathrm{Cd}$ & $\mathrm{H} / \mathrm{O}$ & 0.52 & 0.37 \\
\hline $\mathrm{Sn}$ & 6.18 & 3.35 & 5.11 \\
\hline $\mathrm{Sb}$ & 0.25 & 0.51 & 0.25 \\
\hline $\mathrm{Te}$ & $\mathrm{H} / \mathrm{O}$ & 0.23 & 0.03 \\
\hline Cs & 0.37 & 0.68 & 0.51 \\
\hline $\mathrm{Ba}$ & 19.12 & 249.62 & 56.28 \\
\hline $\mathrm{La}$ & 14.14 & 77.86 & 42.41 \\
\hline $\mathrm{Ce}$ & 22.24 & 110.49 & 59.72 \\
\hline $\operatorname{Pr}$ & 2.43 & 9.55 & 6.39 \\
\hline $\mathrm{Nd}$ & 7.52 & 27.12 & 17.43 \\
\hline $\mathrm{Sm}$ & 1.32 & 5.62 & 2.99 \\
\hline $\mathrm{Eu}$ & 0.14 & 0.61 & 0.27 \\
\hline Gd & 1.51 & 7.61 & 3.95 \\
\hline $\mathrm{Tb}$ & 0.22 & 1.49 & 0.76 \\
\hline Dy & 1.76 & 12.77 & 6.79 \\
\hline Но & 0.51 & 3.38 & 1.78 \\
\hline Er & 2.12 & 13.35 & 6.93 \\
\hline $\mathrm{Tm}$ & 0.39 & 2.51 & 1.22 \\
\hline $\mathrm{Yb}$ & 3.22 & 20.48 & 9.31 \\
\hline $\mathrm{Lu}$ & 0.57 & 3.27 & 1.44 \\
\hline Hf & 25.24 & 58.92 & 25.51 \\
\hline $\mathrm{Ta}$ & 8.12 & 12.09 & 9.56 \\
\hline W & 1.12 & 21.98 & 2.03 \\
\hline $\mathrm{Tl}$ & 1.11 & 2.68 & 1.75 \\
\hline $\mathrm{Pb}$ & 14.64 & 553.84 & 369.21 \\
\hline $\mathrm{Bi}$ & $\mathrm{H} / \mathrm{O}$ & 1.84 & 0.33 \\
\hline Th & 8.45 & 89.75 & 60.66 \\
\hline $\mathrm{U}$ & 8.24 & 28.69 & 11.1 \\
\hline
\end{tabular}


TABLE VI. Composition (\%) and amount (in brackets) of volatile components released during the opening of fluid inclusions in fluorites from granites (E-13) and ores (E-37-13) of the Ermakovskoe deposit (according to GC-MS analysis)

\begin{tabular}{|c|c|c|}
\hline Components & E-13 & E-37-13 \\
\hline Aliphatic hydrocarbons: & $1.82(5)$ & $0.64(4)$ \\
\hline Paraffins & $0.36(2)$ & $0.57(1)$ \\
\hline Olefines & $1.46(3)$ & $0.07(3)$ \\
\hline Cyclic hydrocarbons: & $2.56(9)$ & $0.57(4)$ \\
\hline Cycloalkanes and cycloalkenes & $0.16(1)$ & $0.10(1)$ \\
\hline Arenes & $2.40(8)$ & $0.47(3)$ \\
\hline Oxygen-containing hydrocarbons: & $3.81(26)$ & $0.94(19)$ \\
\hline Alcohols, ethers, and esters & $0.32(3)$ & $0.08(3)$ \\
\hline Aldehydes & $2.22(15)$ & $0.57(14)$ \\
\hline Ketones & $0.44(2)$ & $0.17(1)$ \\
\hline Carboxylic acids & $0.83(6)$ & $0.12(1)$ \\
\hline Heterocyclic compounds: & $0.09(3)$ & $0.01(2)$ \\
\hline Furans & $0.09(3)$ & $0.01(2)$ \\
\hline Nitrogen-containing compounds & $0.62(1)$ & \\
\hline Sulfur-containing compounds & $4.54(17)$ & $13.74(16)$ \\
\hline $\mathrm{CO}_{2}$ & 49.26 & 11.82 \\
\hline $\mathrm{H}_{2} \mathrm{O}$ & 35.10 & 72.20 \\
\hline $\mathrm{O}_{2}$ & 2.18 & 0.08 \\
\hline $\mathrm{Ar}$ & 0.02 & 0.03 \\
\hline Total number of components & 65 & 49 \\
\hline $\mathrm{H} /(\mathrm{O}+\mathrm{H})$ & 0.52 & 0.64 \\
\hline $\mathrm{H} / \mathrm{O}$ & 1.08 & 1.80 \\
\hline $\mathrm{C} / \mathrm{H}$ & 0.35 & 0.05 \\
\hline $\mathrm{C} /(\mathrm{H}+\mathrm{O}+\mathrm{C})$ & 0.15 & 0.03 \\
\hline Alkanes / Alkenes & 0.25 & 8.14 \\
\hline
\end{tabular}

